\title{
The groundwater invertebrate fauna of the Channel Islands
}

\author{
Lee R.F.D. Knight' ${ }^{1}$, Anton Brancelj², Bernd Hänfling ${ }^{3}$, Colin Cheney ${ }^{4}$ \\ I No.1 The Linhay, North Kenwood Farm, Oxton, Nr. Kenton, Devon, EX6 8EX, UK 2 National Institute \\ of Biology, Vecna pot 111, 1000 Ljubljana, Slovenia 3 School of Biological, Biomedical and Environmental \\ Sciences, The University of Hull, HUG 7RX, UK 4 Department of the Environment, States of Jersey Go- \\ vernment, Howard Davis Farm, La Route de la Trinite, Trinity, Jersey, JE3 5JP
}

Corresponding author: Lee R.F.D. Knight (lee.knight01@btinternet.com)

Academic editor: O. Moldovan | Received 26 February 2015 | Accepted 20 April 2015 | Published 25 May 2015

http://zoobank.org/7EFEAOF9-1C74-4D3E-95F5-8DBE156F288D

Citation: Knight LRFD, Brancelj A, Hänfling B, Cheney C (2015) The groundwater invertebrate fauna of the Channel islands. Subterranean Biology 15: 69-94. doi: 10.3897/subtbiol.15.4792

\begin{abstract}
The Channel Islands are a small archipelago of British dependencies just off the coast of Normandy at the western end of the English Channel. There were only three records for stygobitic Crustacea [Niphargus fontanus Bate, 1859 and N. kochianus Bate, 1859 from Jersey and N. aquilex Schiődte, 1855 from Guernsey] from the archipelago and no systematic survey has been carried out of the islands for their groundwater fauna till present. Recently sampling was carried out in wells, boreholes and springs on the four largest islands, Jersey, Guernsey, Alderney and Sark during February 2012. Niphargus aquilex was widespread across all four islands and did not appear to be restricted to any particular geology. Niphargus ladmiraulti was present in large numbers in a single borehole on Jersey, the first record of this species from the archipelago. Niphargus kochianus was collected from two sites on Alderney and the syncarid Antrobathynella stammeri (Jakobi, 1954) from two sites on the west coast of Jersey. The records for A. stammeri are new for the Channel Islands and possibly represent the first records of this species from the French bio-geographical area. The presence of $N$. fontanus on the islands was not confirmed. Several species of stygophilic Cyclopoida were also recorded during the survey along with epigean freshwater invertebrate taxa, which were mostly present in springs and shallow wells close to surface streams.
\end{abstract}

\section{Keywords}

Niphargus, Antrobathynella, Channel Islands, groundwater, stygobitic

Copyright Lee R.F.D. Knight et al. This is an open access article distributed under the terms of the Creative Commons Attribution License (CC BY 4.0), which permits unrestricted use, distribution, and reproduction in any medium, provided the original author and source are credited. 


\section{Introduction}

The Channel Islands (Îles de la Manche) are an archipelago of British Crown dependencies in the English Channel off the coast of Normandy (Figure 1). There are eight inhabited islands: Guernsey, Alderney, Sark, Herm, Jethou, Brecquhou and Lihou, in the Bailiwick of Guernsey and the island of Jersey. In addition there are several groups of uninhabited islets, including Burhou and Les Casquest off the coast of Alderney and the Minquiers, Écréhous, Les Dirouilles and Les Pierre de Lecq which form along with the largest island Jersey, the Bailiwick of the same name.

\section{Previous records of groundwater fauna on the islands}

There are a few previous records of stygobitic Crustacea from the islands but these are quite old and no systematic survey has ever been carried out of groundwater habitats on the archipelago in either a historical or modern context. The Environment Department of the States of Jersey Government carries out a programme of biological monitoring of the island's surface waters and also monitors groundwater levels and chemistry in

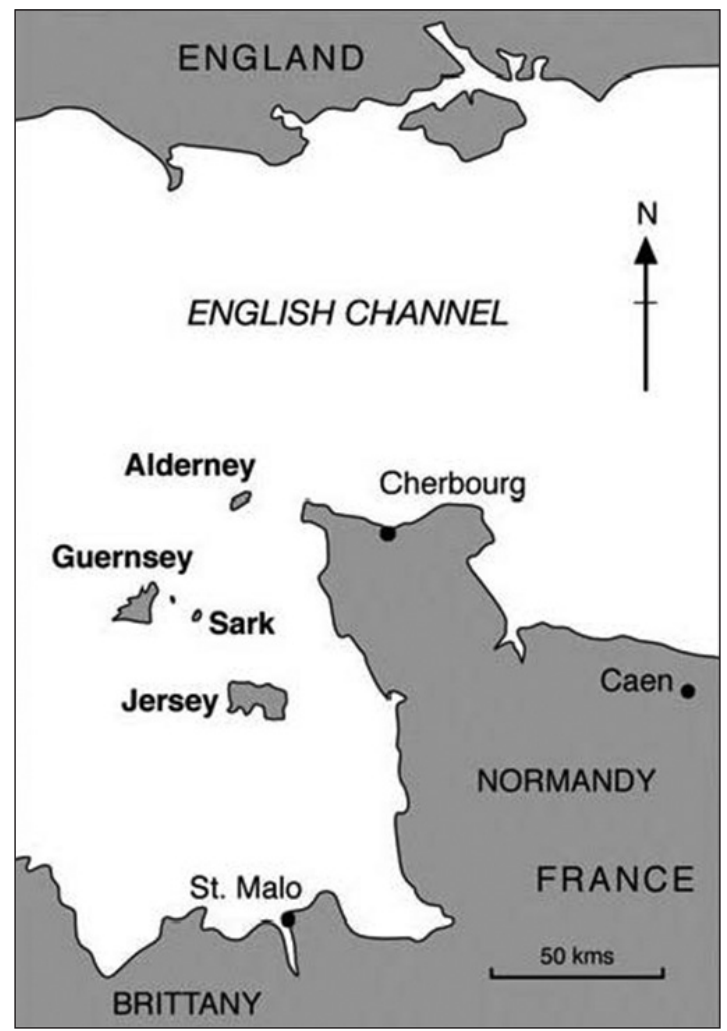

Figure I. The location of the Channel Islands in the English Channel (map from Robins et al. 2012). 
a network of wells and boreholes across the island but no study of groundwater fauna has ever been undertaken. On Sark groundwater levels are monitored in several wells and boreholes across the island on a voluntary basis, with no investigations of the fauna having ever been carried out.

On the UK Biological Records Centre database there is a single record for Niphargus aquilex Schiődte, 1855 collected in 1907 by F.S. Wright from St. Martin on Guernsey (HCRS 2014). Other species recorded from the archipelago include Niphargus fontanus Bate, 1859, recorded by J. Hornell in 1896 from two wells on the outskirts of St. Hellier (Walker and Hornell 1896) and a single juvenile female Niphargus kochianus Bate, 1859, collected from La Ferme Vinchelez on Jersey by F. le Maistre in 1960 (Le Seur 1960).

The purpose of the current investigation was thus to confirm the presence of the above three species on the archipelago and to carry out a detailed, systematic survey of the main islands of the archipelago, which would hopefully discover additional sites and species. The survey was limited to the four largest islands: Jersey, Guernsey, Alderney and Sark where it was thought that stygobitic fauna would be most likely to occur.

\section{Study sites}

\section{Climate and topography}

The Channel Islands have a predominantly temperate maritime climate, with mild winters and warm sunny summers. Average annual rainfall (1981 to 2010) is $870 \mathrm{~mm}$ in Jersey and $839 \mathrm{~mm}$ in Guernsey, with annual average temperatures of 11.3 and $11.4^{\circ} \mathrm{C}$ respectively (Jersey Meteorological office data).

Jersey is the largest island of the group, with a total area of about $117 \mathrm{~km}^{2}$. The island consists of a plateau that has an elevation of between 60 and 120 metres above mean sea level (maximum about 130 metres), gently inclined towards the south. The plateau is divided into a series of north-south deeply incised valleys, which drain the more elevated ground in the north of the island to discharge predominantly along the south coast (Robins and Smedley 1998).

Guernsey is the next largest island with an area of about $64 \mathrm{~km}^{2}$. The island again consists of a plateau, which attains its greatest elevation of over 100 metres in the south west of the island, declining northward and eastward to a low-lying sandy area in the north.

Alderney, the third largest of the island group, has an area of $7.8 \mathrm{~km}^{2}$. The island is similar to the other Channel Islands in having sheer cliffs backing much of the coastline, broken by stretches of sandy beach and dunes. The highest point on the island is at an elevation of about 90 metres, on the central plateau of the island.

Sark is a small island of $5.25 \mathrm{~km}^{2}$ which essentially consists of a gently undulating plateau at an elevation of about 90 metres, with steep cliffs forming much of the coastline. 


\section{Geology}

The islands of Jersey, Guernsey, Alderney and Sark constitute part of the eroded remnants of the Armorican Massif, which is more extensively exposed in Brittany and western Normandy (Robins et al. 2012). The islands largely consist of Precambrian crystalline metamorphic and igneous rocks, together with early Palaeozoic clastic sediments that outcrop on Jersey and Alderney. There is also a thin, but widespread, Quaternary sedimentary cover, deposited prior to the isolation of the islands from mainland France by Holocene sea-level rise.

In Jersey, the Jersey Shale Formation, a series of meta-sediments comprising mudstone, siltstone, greywacke and sandstone with minor grit and conglomerate, outcrops in a broad band through the centre of the island (Institute of Geological Sciences 1982). These are the oldest rocks on the island, being of Upper Proterozoic age, having been deposited between 680 to 570 million years ago (Bishop and Bison 1989). The Jersey Shale Formation is disconformably overlain, in the north east of the island, by a series of volcanic rocks, principally comprising andesite (the St Saviours Andesite Formation) and rhyolites (the St John's Rhyolite and the Bouley Bay Rhyolite Formations), generally considered to be of Lower Paleozoic age (Nichols and Hill 2004). The volcanic series is in turn overlain unconformably to the north east by conglomerates with subordinate sandstones and mudstones (the Rozel Conglomerate Formation) of Ordovician to Silurian age. Intrusive igneous rocks, principally pink granites, gabbros, diorites and granodiorites, considered to be of early Paleozoic age, outcrop at the south west, north west and south east corners of the island. Minor intrusions by many later dolerite, lamprophyre and quartz-feldspar porphyry dykes are common in all of the bedrock strata (Lees 1990).

Guernsey's geology can be divided into two distinct areas. The south of the island consists largely of a metamorphic complex, dominantly metasediments of granitic composition (the 'Icart' Gneiss) and in the centre and west of the island, a foliated quartz diorite (the Perelle' Quartz-Diorite' Gneiss), all cut by a large number of minor intrusions, mostly dykes (Roach et al. 1991). The northern part of the island is underlain by a plutonic igneous complex of Cadomian age, principally of diorite, flanked to the north by granodiorite, to the east by gabbro, and west by granite. Most of these igneous complexes are thought to have been intruded by around 500 million years ago.

Alderney can also be considered as having two geologically distinct areas. The west is underlain by a Precambrian basement, consisting of gneiss and granodiorite, with a feldspathic sandstone (possibly of similar age to the Rozel Conglomerate Formation of Jersey) underlying the east of the island (Robins et al. 2012).

Sark consists of metasedimentary gneisses and younger foliated coarsely crystalline granodiorites of Precambrian age. The gneisses include quartz biotite, augen and quartz dolerite diorite gneiss with darker and lighter bands reflecting former mudstones and sandstones respectively (Robins et al. 2012).

Mesozoic and Cenozoic rocks (including the Upper Chalk and Eocene limestones) occur on the sea bed between the Channel Islands, with Lower Jurassic mudstones and 
Middle Jurassic clay, calcarenites and sandstones to the north of Alderney but none of these deposits occur at outcrop on any of the islands (British Geological Survey 2000).

The deposition of the Ordo-Silurian age conglomerates (Jersey) and sandstone (Alderney) was followed by a hiatus of the order of 500 million years, which left no onshore sedimentary record on any of the islands (Robins et al. 2012). The youngest on-shore strata in the Channel Islands are unconsolidated superficial sedimentary deposits of Pleistocene to Quaternary age, which overlie the ancient bedrock and reflect changing climates and relative sea levels from the Middle Pleistocene to the present day (Keen 1978; 1981). The deposits are largely of inter-glacial or periglacial origin and comprise loess (a widespread distribution across plateau areas), raised beaches (often backed by fossil cliffs), head (periglacial solifluxion breccias), blown sands, peat and alluvium in coastal and valley areas.

\section{Palaeogeography}

During past glacial periods, the Channel Islands would have experienced a much colder climate, but unlike much of the United Kingdom, the islands were not affected by glaciation (Renouf 2009; Jones et al 1990). Sea levels were at a much lower level than at present and the area around the islands would have been dry land. The islands were joined to mainland Europe and would have stood as small upland plateau areas on a plain which extended over the present sea bed area. Sea bed contours suggest that rivers draining mainland France would have flowed between the islands towards the west or north-west, traversing the plain (Renouf 2009).

About 18,000 years ago (during the last glacial maximum (LGM)), sea level would have been over 100 metres below the current level. Sea level is then thought to have risen rapidly to about 75 metres below current level by about 14,000 years ago and to 50 metres about 11,400 years ago; at that time there would still have been dry land between all of the Channel Islands and mainland France (Renouf 2009). At about 10,000 years ago, sea level had risen to about 50 metres below present and had isolated Guernsey, Sark and Alderney from Jersey, which was still attached to France. Alderney was also isolated from Guernsey and Sark at that time. By 9,400 years ago, the sea level was only 20 metres below present levels and Guernsey, Alderney and Sark were isolated from each other. However, it is thought that a land bridge still extended south eastward from Jersey to France but is likely to have been inundated by rising sea levels very shortly after that time (Renouf 2009).

\section{Hydrogeology}

There is, on most (if not all) of the Channel Islands, a long-held traditional belief that groundwater at depth is derived from a source in mainland France. The Alps and the Pyrenees in the past have been suggested by water diviners as a possible source of 
groundwater in Jersey (as reported in the Jersey Evening Post of 27 July 2004) but more recently 'Petite Suisse (or Suisse Normande)' located to the south of Caen has also been put forward as a potential source (Jersey Evening Post of 13 October 2005; States of Jersey, Vibert Scrutiny Panel 2004) but without any tangible evidence to support such theories. It has been asserted that this groundwater flows in streams beneath the sea to sustain the 'deep aquifer' beneath the Island. However, detailed research carried out in Jersey, has demonstrated that the origin of all groundwater on the island is from local rainfall and that there is no evidence to suggest that either the shallow or deep groundwater beneath Jersey has a source that is located outside of the Island (Cheney et al. 2006). This will undoubtedly be the case for the other Channel Islands .

The bedrock aquifer in the Channel Islands consists of hard fractured rocks, which possess minimal primary (inter-granular) porosity or permeability and in consequence, broadly similar hydrogeological conditions are found on all of the islands (Davies 1998; Robins et al. 2002; Robins et al 2012). Groundwater flow and storage occurs almost entirely within joints, fractures and faults within the rock mass (Robins and Smedley 1998). Borehole yields are therefore dependent on the number, size and degree of lateral and vertical interconnection between the fractures. In common with similar aquifers elsewhere, fractures are generally most common, larger and better interconnected at relatively shallow depths, generally becoming fewer, less dilated and less well interconnected with increasing depth. Total yields commonly increase cumulatively with depth, as a borehole penetrates an increasing number of productive fractures (Cheney et al. 2006). Higher yields are normally obtained from the zone that occurs a few tens of metres below the water table. Usable and high yields can however sometimes be obtained at depth from occasional more productive fractures (Robins and Smedley 1998).

In Jersey, the Quaternary sands along the west and parts of the east coasts of the island, although of limited extent, also form a productive aquifer (Robins and Smedley 1998). Similar deposits on the other islands may also constitute aquifers of limited extent, where the deposits are saturated and of sufficient permeability.

In Jersey, groundwater flow is predominantly from the high ground in the north of the island where the water table attains the highest elevation, towards the south. In Guernsey the groundwater flow is predominantly from the high ground in the south towards the east and north, with shorter steeper flow gradients towards the south (Robins et al. 2000). Groundwater flow in the smaller islands of Alderney and Sark: the water table attains the maximum elevation near the centre of the islands and groundwater flow is effectively radial towards the coast.

\section{Methods}

\section{Survey strategy}

The Ordnance Survey of Britain does not cover the archipelago but there are two locally produced maps that encompass the 'main islands': the 20091 : 25000 map of 


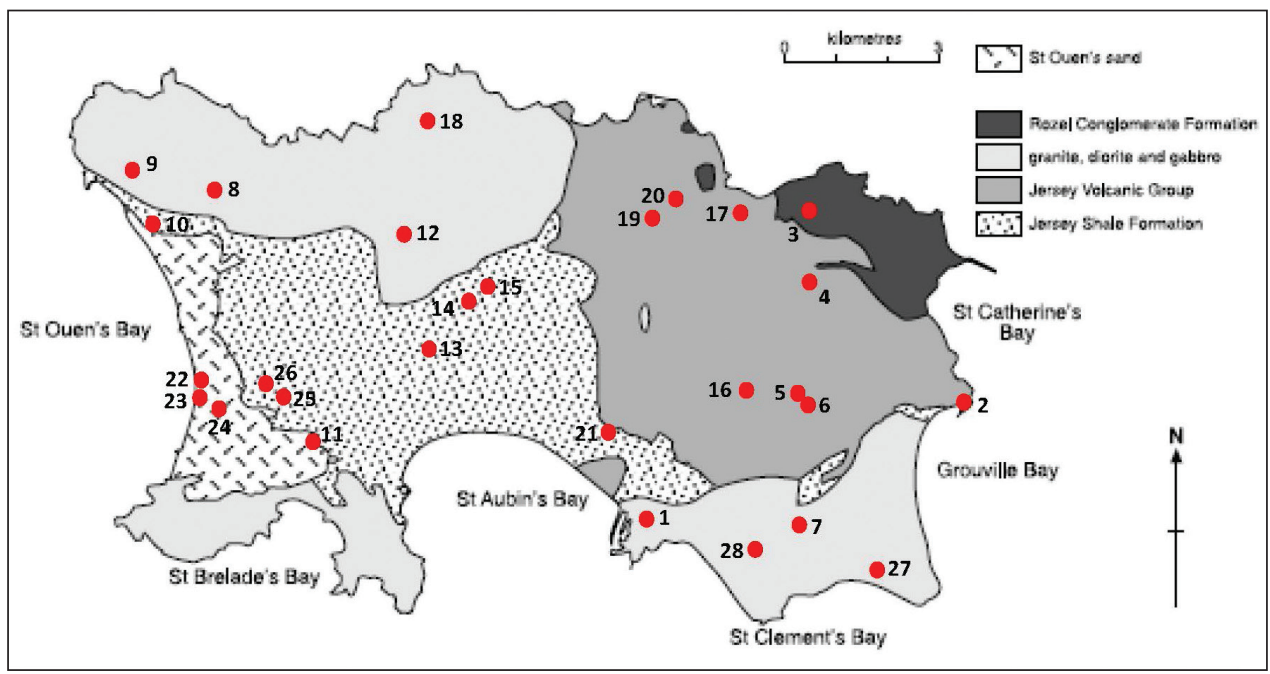

Figure 2. The locations of sampling sites on Jersey (map from Rose 2005).

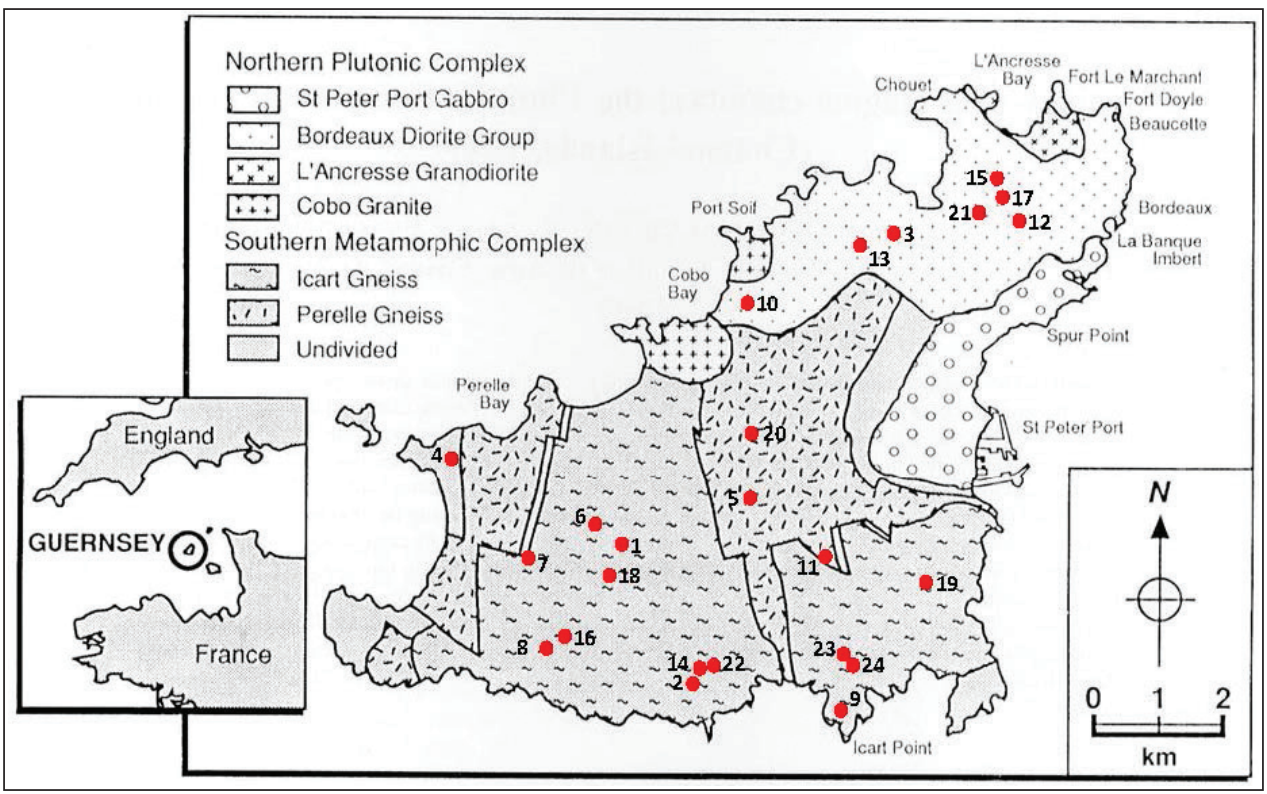

Figure 3. The locations of sampling sites on Guernsey (map from Roach et al. 1991).

Jersey, produced by the States of Jersey Planning and Environment Department and the 2011 1: 15000 / 1: 10000 map of the Bailiwick of Guernsey (encompassing Guernsey, Sark, Herm, Alderney and Jethou and Brecqhou) produced by the States of Guernsey. There are also various published geological maps of the islands, four of which have been used as the basis for the figures below. Using these maps and local knowledge [States of Jersey Department of the Environment; La Société Guernesiaise 


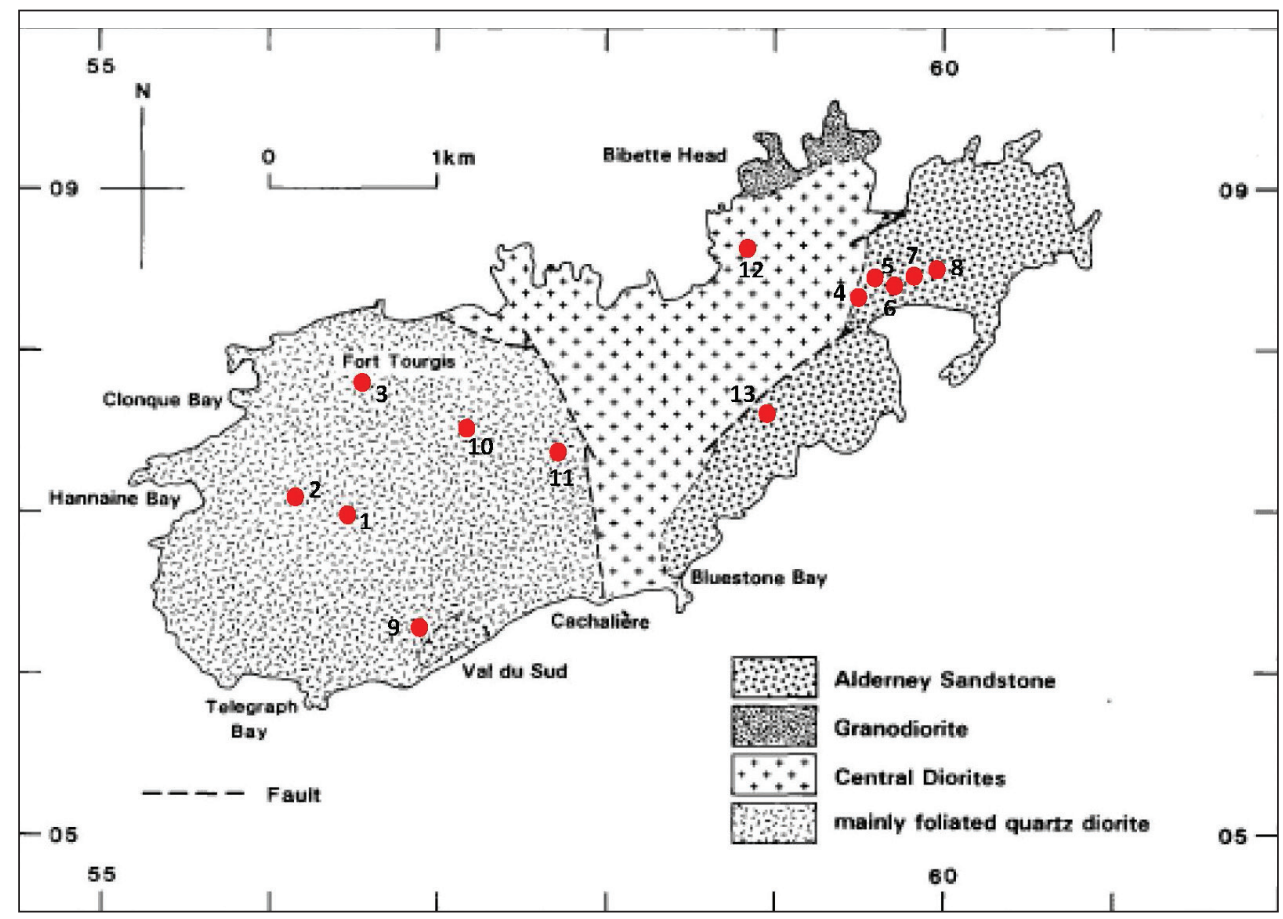

Figure 4. The locations of sampling sites on Alderney (map from Tribe et al. 1993).

/ Guernsey Biological Records Centre; La Société Serquiaise; and Alderney Wildlife Trust] a selection of sampling site locations, illustrated in Figures 2 to 5 were chosen to encompass a geographical spread across each island and also to try and include sites on a diverse range of geologies.

Although groundwater sampling sites can include a variety of different types, from surface springs and seepages to wells and boreholes, the latter were preferentially chosen for sampling so as to minimise surface influence and the occurrence of epigean fauna. Only two springs were sampled, both at St. Martin on Guernsey [Le Navet and Saints Road]. However, the wells at London House on Jersey and Hivernage, Hudsons and La Fougeraie on Sark were located at the risings of springs and hence the water within them was close to ground level. Field work was carried out during one visit in February 2012.

\section{Sampling methods}

At each borehole or well samples of the subterranean fauna were collected by lowering on the end of a $100 \mathrm{~m}$ cable a phreato-biological sampling net [100 $\mu \mathrm{m}$ mesh size, based on the pattern of Cvetkov (1968)], fitted with a screw-on filter and a metal 


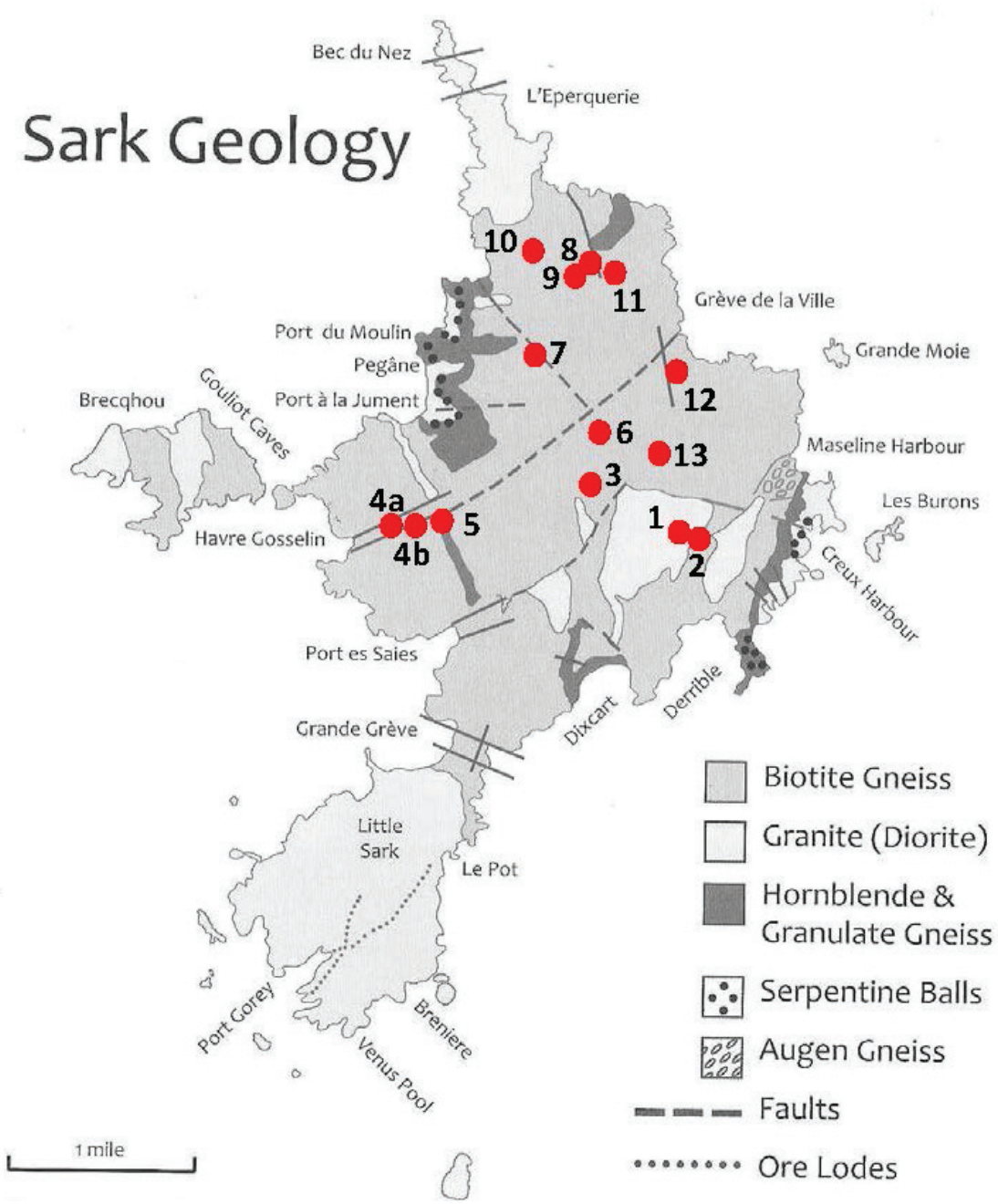

Figure 5. The locations of sampling sites on Sark (map from Belfield 2012).

weight suspended below it, to the base of the shaft. The diameter of the net used varied from 5 to $30 \mathrm{~cm}$, using the largest diameter possible, relative to the borehole aperture. On reaching the base, the weighted net was lifted a metre or so and dropped to agitate the bottom sediment and suspend any fauna that might be present into the water. This action was repeated six times before the net was hauled up through the water column to the surface, collecting suspended debris and fauna on the way. The process was repeated with three net hauls recovered from each site in total.

At shallow wells and spring sites, a more manoeuvrable, small pond net $[15 \mathrm{~cm}$ diameter mouth, fitted with a $100 \mu \mathrm{m}$ mesh bag] was used. Additional pole sections could be fitted to the net as required, to make a total handle length of up to $3 \mathrm{~m}$. 


\section{Sample analysis}

Following collection, samples were preserved in $90 \%$ ethanol for transportation back to the laboratory, where they were washed through a graded series of sieves [the lowest of $63 \mu \mathrm{m}$ mesh] and fractions were sorted beneath a stereo microscope. Where possible, aquatic invertebrate fauna were identified to the lowest taxonomic level; Chironomidae, Oligochaeta, Ostracoda, Oribatei, terrestrial Acari and Collembola were not identified further.

After completion of the field work and analysis, the following Niphargus aquilex specimens were sent to the School Of Biological, Biomedical and Environmental Science at Hull University for molecular studies: Jersey: Grouville Spring 2, Fort Regent 2, Field MT715 1, London House 2; Guernsey: Newhaven 1, Vieux Belial 1, Le Navet 4, Les Niaux 4, Gooder House 3; Alderney: Longis Common BH1 1, Tourgis Well 1; Sark: Seigneurie 2, La Tour 2, Museum 1, La Forge 1. In addition to the above, three $N$. kochianus specimens from Longis Common $\mathrm{BH} 1$ and one from Well House on Alderney were sent.

\section{Results}

The depths of the well and borehole shafts sampled varied from just below the ground surface to the massive, deep well at Fort Regent on Jersey, which was blasted through the granite to a depth of $92 \mathrm{~m}$. They also displayed various degrees of connectivity with the surface; some were sealed with heavy manhole covers, whilst some shafts were topped with small stone 'well houses' and were open at the surface. Mostly the shallow open wells [but also to a lesser degree some of the deep / sealed wells] contained a proportion of epigean taxa, including: the flatworm Polycelis felina (Dalyell, 1814), the hydrobiid snail Potamopyrgus antipodarum (Gray, 1834), the pea mussel Pisidium personatum Malm, 1855, the amphipods Gammarus pulex (Linnaeus, 1758) and Crangonyx pseudogracilis Bousfield, 1958, the isopods Asellus aquaticus (Linnaeus, 1758) and Proasellus meridianus (Racovitza, 1919), the Trichoptera larvae Plectrocnemia conspersa (Curtis, 1834), P. geniculata McLachlan, 1871, Wormaldia occipitalis (Pictet, 1834) and Beraea maurus (Curtis, 1834), aquatic Diptera larvae (Chironomidae, Psychoda sp., Trichyphona sp., Sphaeromias sp., Palpomyia / Bezzia gp. and Culiseta alaskaensis gp.) and the riffle beetle Elmis aenea (Müller, 1806).

Deeper, sealed wells mostly contained stygobitic amphipods or stygoxenic/stygophilic Copepoda; no stygobitic Copepoda were collected. As groups such as the Oligochaeta and Nematoda were not determined further it was unknown if species with an affinity for the groundwater environment were present.

A total of 28 invertebrate taxa were recorded from the 30 sites on Jersey (see Suppl. material 1 - which contains Table 2; Table 1 is present in text below), among them three stygobitic species: the amphipods Niphargus aquilex and Niphargus ladmiraulti Chevreux, 1901 and the syncarid Antrobathynella stammeri (Jakobi, 1954). 
Table I. Summary of Invertebrate taxa recorded from the four islands (X indicates present in samples).

\begin{tabular}{|c|c|c|c|c|}
\hline TAXA & Jersey & Guernsey & Alderney & Sark \\
\hline \multicolumn{5}{|l|}{ TRICLADIDA } \\
\hline Polycelis felina & & $\mathrm{X}$ & $\mathrm{X}$ & $\mathrm{X}$ \\
\hline NEMATODA & & $\mathrm{X}$ & $\mathrm{X}$ & $\mathrm{X}$ \\
\hline OLIGOCHAETA & $\mathrm{X}$ & $\mathrm{X}$ & $\mathrm{X}$ & $\mathrm{X}$ \\
\hline \multicolumn{5}{|l|}{ GASTROPODA } \\
\hline Indeterminate juvenile gatropoda spp. & & & & $\mathrm{X}$ \\
\hline Potamopyrgus antipodarum & $\mathrm{X}$ & & & $\mathrm{X}$ \\
\hline \multicolumn{5}{|l|}{ BIVALVIA } \\
\hline Pisidium personatum & $\mathrm{X}$ & $\mathrm{X}$ & & $\mathrm{X}$ \\
\hline Pisidium sp. & $\mathrm{X}$ & & & $\mathrm{X}$ \\
\hline \multicolumn{5}{|l|}{ CRUSTACEA } \\
\hline \multicolumn{5}{|l|}{ SYNCARIDA } \\
\hline Antrobathynella stammeri & $\mathrm{X}$ & & & \\
\hline \multicolumn{5}{|l|}{ AMPHIPODA } \\
\hline Gammarus pulex & $\mathrm{X}$ & & $\mathrm{X}$ & $\mathrm{X}$ \\
\hline Crangonyx pseudogracilis & $\mathrm{X}$ & $\mathrm{X}$ & & \\
\hline Niphargus aquilex & $\mathrm{X}$ & $\mathrm{X}$ & $\mathrm{X}$ & $\mathrm{X}$ \\
\hline Niphargus ladmiraulti & $\mathrm{X}$ & & & \\
\hline Niphargus kochianus & & & $\mathrm{X}$ & \\
\hline Arcitalitrus dorrieni & & & & $\mathrm{X}$ \\
\hline \multicolumn{5}{|l|}{ ISOPODA } \\
\hline Asellus aquaticus & & & $\mathrm{X}$ & \\
\hline Proasellus meridianus & $\mathrm{X}$ & & & $\mathrm{X}$ \\
\hline \multicolumn{5}{|l|}{ CLADOCERA } \\
\hline Daphnia pulex & $\mathrm{X}$ & & & \\
\hline OSTRACODA & $\mathrm{X}$ & $\mathrm{X}$ & & $\mathrm{X}$ \\
\hline \multicolumn{5}{|l|}{ COPEPODA } \\
\hline Cyclops furcifer & & & $\mathrm{X}$ & \\
\hline Diacyclops bicuspidatus & $\mathrm{X}$ & $\mathrm{X}$ & & $\mathrm{X}$ \\
\hline Diacyclops bisetosus & $\mathrm{X}$ & $\mathrm{X}$ & $\mathrm{X}$ & $\mathrm{X}$ \\
\hline Diacyclops languidus & $\mathrm{X}$ & & & \\
\hline Eucyclops serrulatus & $\mathrm{X}$ & $\mathrm{X}$ & $\mathrm{X}$ & $\mathrm{X}$ \\
\hline Megacyclops viridis & & $\mathrm{X}$ & $\mathrm{X}$ & $\mathrm{X}$ \\
\hline Macrocyclops albidus & $\mathrm{X}$ & & & \\
\hline Paracyclops fimbriatus & $\mathrm{X}$ & $\mathrm{X}$ & $\mathrm{X}$ & $\mathrm{X}$ \\
\hline Thermocyclops cf. oithonoides & $\mathrm{X}$ & & & \\
\hline Tropocyclops prasinus & & & $\mathrm{X}$ & $\mathrm{X}$ \\
\hline Cyclopoida spp. & $\mathrm{X}$ & $\mathrm{X}$ & & \\
\hline HARPACTICOIDA & & & & $\mathrm{X}$ \\
\hline \multicolumn{5}{|l|}{ ACARI } \\
\hline Oribatei spp. & $\mathrm{X}$ & & & \\
\hline Acari spp. (non-aquatic) & $\mathrm{X}$ & $\mathrm{X}$ & $\mathrm{X}$ & $\mathrm{X}$ \\
\hline COLLEMBOLA & $\mathrm{X}$ & $\mathrm{X}$ & $\mathrm{X}$ & $\mathrm{X}$ \\
\hline TRICHOPTERA & & & & \\
\hline
\end{tabular}




\begin{tabular}{l|c|c|c|c}
\hline TAXA & Jersey & Guernsey & Alderney & Sark \\
\hline Plectrocnemia conspersa & & $\mathrm{X}$ & & \\
\hline Plectrocnemia geniculata & & & $\mathrm{X}$ & \\
\hline Plectrocnemia sp. & & $\mathrm{X}$ & & $\mathrm{X}$ \\
\hline Wormaldia occipitalis & & $\mathrm{X}$ & & \\
\hline Beraea maurus & $\mathrm{X}$ & & & \\
\hline DIPTERA & & & & \\
\hline CHIRONOMIDAE & $\mathrm{X}$ & $\mathrm{X}$ & $\mathrm{X}$ & $\mathrm{X}$ \\
\hline CERATOPOGONIDAE & & & & \\
\hline Sphaeromias sp. & $\mathrm{X}$ & $\mathrm{X}$ & & \\
\hline Palpomyia / Bezzia gp. & & & & $\mathrm{X}$ \\
\hline Ceratopogonidae sp. (pupa) & $\mathrm{X}$ & & & \\
\hline Culiseta alaskaensis gp. & $\mathrm{X}$ & & & $\mathrm{X}$ \\
\hline Culicinae sp. & $\mathrm{X}$ & & & \\
\hline Psychoda sp. & $\mathrm{X}$ & $\mathrm{X}$ & $\mathrm{X}$ & \\
\hline Trichyphona sp. & $\mathrm{X}$ & & & \\
\hline COLEOPTERA & & & & \\
\hline Elmis aenea & $\mathrm{X}$ & & & \\
\hline
\end{tabular}

Niphargus ladmiraulti was recorded in large numbers (62 specimens) in the well at Sous les Bois, Trinity (site 17), in the Bouley Bay Rhyolite, along with four specimens of $N$. aquilex. This was the only location at which $N$. ladmiraulti was recorded throughout the archipelago. Three other sites were also sampled in the same geological formation but only one of them, site 4 [field MT715 borehole] produced a single $N$. aquilex specimen. Specimens of $N$. aquilex were additionally collected from nine further sites across the island, encompassing a range of geologies, including the Granite formations [south-east and north-west] (sites 1, 2c, 7, 8, 12 and 18), St. Saviours Andesite (site 5), Jersey Shale Formation (site 10), and Diorite (site 28). Antrobathynella stammeri was recorded from two observation boreholes at the St. Ouen's Sandpit (sites 22 and 23), both in Quaternary blown sand deposits.

Niphargus kochianus was previously recorded from a single site on Jersey. It was not recorded on Jersey during the current study, thus its occurrence on that island has not been confirmed. It was however recorded for the first time on Alderney and the old record in Le Seur from 1960 is thus likely to be accurate. Niphargus fontanus was not collected during the survey, thus its presence on the archipelago and the 1896 records from Jersey have not been confirmed.

Niphargus aquilex was the only stygobitic species recorded on Guernsey, where it was recorded from 12 of the 26 sampling locations, across a wide geographical spread. It was found on the Icart Gneiss (sites 6, 14, 18, 19 and 23), the Perelle Gneiss (sites 5 and 11) and Undivided metamorphic formation (site 4) in the south and on the Bordeaux Diorite Group (sites 3, 10a, 10b and 15) in the north. Its presence at Gooder House (site 11), and Le Navet spring (site 23), both in St. Martin confirm the 1907 record for this species from the same parish. Nineteen invertebrate taxa in total were recorded during the survey (see Suppl. material 2 - Table 3). 
Both $N$. aquilex and N. kochianus were recorded on Alderney, where a total of 18 invertebrate taxa were recorded from the 13 sampling locations (see Suppl. material 3 - Table 4). Niphargus aquilex was recorded at six sites across the island encompassing the western diorite (sites 2, 9,10), the central diorite (site 12) and the Alderney Sandstone (sites 4 and 13). Niphargus kochianus was collected from two locations in the east of the island, on the sandstone: a borehole on Longis Common (site 5) and Well House (site 8).

Twenty four invertebrate taxa were recorded from Sark (see Suppl. material $4-$ Table 5), including N. aquilex, recorded from 11 of the 14 sampling sites. Most of the sampling sites were located in the north of the island, on the gneiss, with just one (site 1) on the grandiorite (granite) and a second site (site 2) located on the border between the two geologies. Niphargus aquilex was widespread across the island, including site 2 but not site 1 .

Among the Copepoda, ten species were determined. Three (Cyclops furcifer Claus, 1857, Tropocyclops prasinus (Fischer, 1860) and Thermocyclops cf. oithonoides (G.O. Sars, 1863)) are stygoxenes and can survive only for a short time in the groundwater environment. Those more tolerant of the groundwater environment (facultative stygophiles) were: Diacyclops bisetosus (Rehberg, 1880), Eucyclops serrulatus (Fischer, 1851), Macrocyclops albidus (Jurine, 1820), Megacyclops viridis (Jurine, 1820) and Paracyclops fimbriatus (Fischer, 1853); while pronounced stygophilic nature (obligatory stygophiles) is expressed in Diacyclops bicuspidatus (Claus, 1857) and D. languidus (Sars, 1863).

Three species: $D$. bisetosus, E. serrulatus and P. fimbriatus were collected on all four islands. Others were collected on three (D. bicuspidatus and $M$. viridis), two (T. prasinus) or one island (C. furcifer, T. cf. oithonoides, D. languidus and Macrocyclops albidus).

\section{Discussion}

\section{Distribution of stygobites in the groundwater of the Channel Islands}

Niphargus aquilex was the most widespread stygobitic species on the archipelago, occurring at a high proportion of sites on all four of the islands included in the survey. The species is widespread in Europe, occurring across a large area ranging over a distance of about $2300 \mathrm{~km}$ from the British Isles to Greece. Recent molecular studies have however revealed that what was thought to be a very widespread species is in fact divided into several cryptic taxa, encompassing considerably smaller ranges (Trontelj et al. 2009). Even within Britain three cryptic taxa of the $N$. aquilex complex have been identified one of which appears to be endemic (McInerney et al. 2014). In France $N$. aquilex is recorded as having a scattered distribution throughout the country, being most common in the north (Ginet 1996). Within Britain it occurs across southern England and Wales, with several outlying records north of the Devensian glacial limit. It is the most common and widely distributed of the British niphargids, occurring in a variety of geologies including the granite of Dartmoor 
in the south west (Proudlove et al. 2003; HCRS 2014). The species was previously only known from Guernsey and thus the new records in the current study represent the first documented occurrence of the species on Jersey, Sark and Alderney. The preliminary results obtained from nuclear and mitochondrial sequences show that $N$. aquilex from Alderney are genetically very closely related to the populations from mainland Britain whereas the samples from the remaining islands form a distinct highly divergent lineage, possibly another cryptic species.

The N. kochianus-group in north-western Europe consists of a collection of four species with very close morphological traits that were formerly designated as sub-species. These were identified by Stock and Gledhill (1977) as: Niphargus kochianus kochianus [cf. Niphargus kochianus], known from southern England; N. kochianus dimorphopus [cf. Niphargus dimorphopus] (Stock \& Gledhill, 1977), known from south-eastern Netherlands and eastern Belgium; N. kochianus irlandicus [cf. Niphargus irlandicus] (Schellenberg, 1932), known from Ireland; and Niphargus pachypus (Schellenberg, 1933), known from south-eastern Netherlands to southern France. Molecular studies by Hänfling et al. (2008) and McInerney et al. (2014) have concluded that whilst $N$. kochianus and $N$. dimorphopus are closely related sister taxa, $N$. irlandicus and $N$. kochianus have not shared a common ancestor since the Miocene and hence both have since been elevated to species rank cf. Niphargus irlandicus and Niphargus kochianus.

N. pachypus is currently known from the Pas-de-Calais to the Pyrénées-Orientales in France, as well as the Netherlands, Belgium and Luxembourg (Karaman and Ruffo 1986). Niphargus dimorphopus is included in Ginet's publication (Ginet 1996), who describes it as occurring in "eaux souterraines du continent européen." Stock and Gledhill (1977) describe $N$. dimorphopus as being known with certainty only from the province of Limburg in the Netherlands and eastern Belgium and that other finds from elsewhere in Belgium, Germany and France require confirmation.

Within Britain N. kochianus occurs across southern England from Norfolk and Kent in the east to Gloucestershire and Dorset in the west. It is not currently known from the far south west [Devon and Cornwall] or Wales (Proudlove et al. 2003; HCRS 2014). Gledhill and Stock (1977) and Proudlove et al. (2003) consider it to be a British endemic sub-species. However Vonk (1988) reported it from the Aquitanian basin of south-western France and it was subsequently included in Ginet (1996). Recent sampling during the PASCALIS project (Protocol for the Assessment and Conservation of Aquatic Life In the Subsurface) also recorded the species in the Jura region of east France (Dole-Olivier et al. (2009). Within southern England there appears to be a close correlation between the Chalk and the distribution of $N$. kochianus (Proudlove et al. 2003), an association also reported by Vonk (1988) in France. The presence of the species on Alderney suggests that it is highly likely that $N$. kochianus also occurs in nearby France, although the geology from which it was recorded is atypical of the species. It is possible that it was common within the Upper Chalk and Eocene limestones of the submerged plain that linked the islands and France prior to marine inundation and that the ancestors of the present population retreated to the north east corner of Alderney where they have since become isolated. 
Further molecular studies are in progress to elucidate the relationship of the Alderney specimens with British and French populations of $N$. kochianus. Previous studies (Stock and Gledhill 1977; Hänfling et al. (2008); McInereney et al. (2014) have shown that British, Belgian and French members of the N. kochianus group appear to be highly divergent. Preliminary results indicate that the $N$. kochianus individuals from Alderney appear to be genetically closely related to the British mainland populations rather than to French populations. This supports the initial results obtained from the molecular analysis of the $N$. aquilex specimens described above, in that Alderney appears to be inhabited by Niphargus lineages that are closely related to those of Britain and different to the other three islands. Alderney is the closest of the islands to both Britain and France but is much closer to the latter, suggesting that it would possibly have more similarity to the fauna of France. However, it would seem that in terms of distance the French populations of $N$. aquilex and $N$. kochianus are further from Alderney than that island is from the southern coastline of Britain.

The large numbers of $N$. ladmiraulti from the well at Sous Les Bois on Jersey are the first and only record of this species from the Channel Islands. The species is not known from Britain but occurs throughout the west of France, including nearby Normandy and Brittany (Ginet 1996). We expected it to be more wide-spread over the archipelago according to its abundance, but so far it has only been recorded from the one location.

Niphargus fontanus was not collected during the survey, thus its presence on the archipelago is only documented by records almost 120 years old (Walker and Hornell 1896). It has a scattered distribution in France (Ginet 1996) and Karaman and Ruffo (1986) list the species as occurring in eastern France, Belgium, Germany and Austria. In Britain the species is recorded from wells, boreholes, springs and cave systems across southern England and Wales.

The records of the syncarid A. stammeri on Jersey are also the first for the archipelago. Throughout Europe the species is known from Germany, Austria, Italy, Romania and the Czech Republic (Botosaneanu 1986; Proudlove et al. 2003) with recent discoveries in the Netherlands (Notenboom and De Boom 1990) and Belgium (Fiers 2007). It is also known from a single hyporheic site on the river Flesk in Killarney, Ireland and has a wide but disjunct distribution in the British Isles from Devon to the Midland Valley in Scotland (Proudlove et al. 2003; HCRS 2014); with recent records from the Ogof Draenen cave system in South Wales. It has been recorded from springs, the hyporheic zone, boreholes and caves. The species is not currently known in France, although 17 other species of the Bathynellidae have been recorded (Camacho and Valdecasas 2008), including Bathynella natans Vejdoysky, 1882 (Vandel 1964), which shares many morphological features with this species. Gledhill et al. (1993) and Proudlove et al. (2003) discuss the fact that similarities between these two species has caused confusion amongst the British records, with early records of the species being described as $B$. natans. Re-examination of some of the earlier specimens and all post 1960 records have been confirmed as $A$. stammeri and it is now believed that only this species is present in the British Isles. Both species of syncarid are very small and the 
confusion associated with their identification, coupled with their very small size could imply that $A$. stammeri has been overlooked in France. Currently, the records from the Channel Islands could represent the first records from the French bio-geographical area. Although also recorded from caves the species is more commonly associated with aquifers in unconsolidated fine gravels and sand, such as the aquifer at St. Ouen.

An interesting record was a tiny snail recorded from the well at Clos-a-Jaon on Sark (site 6). There are several stygobitic hydrobiid species that occur in subterranean waters across Europe but unfortunately the single miniscule specimen was juvenile and rather fragile. Harriet Wood, the Collections Manager Mollusca at the National Museum of Wales, Cardiff tentatively identified it as Skenea sp. or a juvenile Rissoella, although with little confidence. Both of these are marine genera and the $15 \mathrm{~m}$ deep well was some $500 \mathrm{~m}$ from the coast line, thus the specimen was unlikely to have been a marine species.

\section{Presence of stygophile and stygoxene taxa in the groundwater of the Channel Islands}

Most of the copepod species collected during the survey have been recorded from groundwater in the British Isles; although none are stygobiotic, they can survive for some time in or have stygophilic affinities to the groundwater environment. The higher energetic requirements of epigean species (i.e. stygoxenes) which prevent their existence in subterranean environments for extended periods have been well studied in amphipods (Mezek et al. 2010). In Britain D. bicuspidatus has been collected from many wells in chalk, remote from surface water and in association with $N$. fontanus and $N$. kochianus and is also known from at least three caves. During a survey of Irish groundwater fauna Arnscheidt et al. (2008 2012) found this to the most common occurring species of cyclopid recorded, closely followed by Diacyclops bisetosus. Diacyclops bicuspidatus was also usually present in the greatest numbers and was recorded from both wells and boreholes. Diacyclops bisetosus occurs in wells and springs; including recent records from several covered wells and springs on the Scilly Isles (Knight 2009). Diacyclops languidus (probably as a complex of cryptic species; see Stoch 2010) is known from wells in Britain and Ireland and from a cave on the Mendip Hills. Arnscheidt et al. (2012) considered D. bicuspidatus and D. bisetosus to be stygophilic whilst Proudlove et al. (2003) also judged D. bicuspidatus to be a possible stygophile in Britain. Arsncheidt et al. (2012) mention that the three Diacyclops species are frequently associated with groundwater and that there is evidence of cryptic speciation within the genus, as also indicated by Stoch (2010). Irish specimens showed morphological variations that further suggested such speciation and the possibility that animals in subterranean habitats could form distinct populations from those on the surface (Arnscheidt et al. 2012).

Megacyclops viridis is known from several caves and wells in Britain and Ireland and is likely to be a stygophile or at least quite tolerant of the groundwater environment. Wood et al. (2002) regarded it as stygophilic within the Peak-Speedwell system in the Derbyshire Peak District. Eucyclops serrulatus has a similar tolerance of the groundwater 
environment and is quite common in springs and cave entrances all over Europe (Einsle 1993).

Paracyclops fimbriatus has been recorded deep in Otter Hole, a large cave system in South Wales by Chapman (1979), who considers it a stygophile. Also recorded from the autogenic stream in the Black Hole Series of Swildon's Hole (Knight 2011) and recently collected from Llanedwen borehole on the island of Anglesey off the coast of north Wales. This latter site is an $80 \mathrm{~m}$ deep Environment Agency monitoring borehole in Carboniferous limestone, where the species was recorded along with the subterranean amphipod $N$. aquilex. The species is known from various other caves and wells, supporting Chapman's supposition that it is stygophilic.

The occurrence of Cyclops furcifer, Thermocyclops cf. oithonoides and Tropocyclops prasinus in the samples is accidental; representatives of these species can survive in shallow wells or boreholes for some time but can't reproduce there, all three species typically occur in lake pelagic zooplankton communities (Einsle 1993). Cyclops furcifer was recorded once from the Pottery on Alderney (site 25), a shallow, open tank that forms more of an underground cistern than a well per se. Two specimens of Thermocyclops cf. oithonoides were collected from the well at London House on Jersey (site 18), which although sealed with a wooden door was very shallow and close to a surface stream; Pisidium personatum and chironomid larvae were recorded the same location. Tropocyclops prasinus was recorded from the well at 'Well House' (site 8) on Alderney, along with $N$. kochianus and $M$. viridis; although the well was $5 \mathrm{~m}$ deep, the top of the shaft was approximately $1.5 \mathrm{~m}$ wide and open at the surface. The same species was also recorded from several wells on Sark. Two of these, La Fougeraie (site 11) and Hudsons (site 1) were very shallow wells at the sources of springs. Le Fort (site 8) and Fregondee Well 2 (site 4b) were both shallow wells with open shafts. Its occurrence in the wells at La Peigneurie (site 1) and La Forge (site 2), albeit in very small numbers was more unusual in that both were deep shafts sealed with a wooden door.

Specimens of the amphipod Gammarus pulex were collected from the well to the west of the Valle de Saul on Sark (site 9) and from the village well at La Villaise on Jersey (site 9). Although both well shafts were sealed, other epigean freshwater taxa were recorded, indicating connections with surface waters nearby. Gammarus pulex has been known to form substantial stygophilic populations in many British caves, some of which exhibit varying degrees of depigmentation and ocular regression (Proudlove et al. 2003; Knight 2011).

Another amphipod species Crangonyx pseudogracilis was recorded from the well at La Cachette on Guernsey (site 4) and from two boreholes (sites 24 and 25) on Jersey. All three sites were sealed shafts with no other epigean taxa present, although stygophilic copepods were present. Although the La Cachette well was only $3 \mathrm{~m}$ deep, the two boreholes were $16 \mathrm{~m}$ and $14 \mathrm{~m}$ deep respectively. Crangonyx pseudogracilis is a naturalised species introduced from North America to Britain and Europe that is widespread in ponds, ditches and the slow sections of rivers and streams (Gledhill et al. 1993) but is rarely recorded from subterranean habitats. Knight (2011) recorded it at several locations along the main stream in a cave in the Mendip Hills of Somerset, 
England and it has also been recorded in England from temporary pools and sometimes shallow, sealed wells with no other surface water- bodies nearby (L. Knight, personal records). Harris et al. (2002) demonstrated that it can migrate through the groundwater to reach temporary ponds, although whether it is actually a stygophile is open to debate.

Two isopod species Asellus aquaticus and Proasellus meridianus were also recorded from various sites; on the surface both species are characteristic of ponds, ditches and slow-flowing sections of rivers and streams. A single Asellus aquaticus was recorded from the $4 \mathrm{~m}$ deep well at Rose Farm on Alderney (site 1). Asellus aquaticus has been recorded from a small stream deep underground in a cave in the Mendip Hills (Knight 2011) and recently several specimens were collected from the lake in Pen Park Hole (a cave under Bristol, also in south west England) which has been isolated from the surface for some considerable time (Knight 2014). Some specimens have been noted to display varying degrees of depigmentation; Knight and Penk (2010) recorded de-pigmented Asellus aquaticus in several Irish caves and also specimens that lacked eye spots in Crag lower Cave, Co. Kerry, also recorded by Arnscheidt et al. (2012). The well at Rose Farm was open at the surface and was close to a pond and it is likely that the specimen found its way into the well via a pathway beneath the pond's base. Asellus aquaticus has been collected in similar circumstances from the entrance pool and flooded passages of Fire Cave, on the banks of the River Lemon in south Devon, England (L. Knight, personal records). A subterranean sub-species Asellus aquaticus cavernicola Racovitza, 1925 occurs in Italy and Slovenia but is not known from Western Europe.

Proasellus meridianus was recorded from the $18 \mathrm{~m}$ Main Well (site 2a) and the 17 $\mathrm{m}$ deep Inner Ward Well (site 2b) at Gorey Castle on Jersey and although both shafts were open at the surface there are no surface water-bodies nearby. Proasellus meridianus was also recorded in several wells on Sark, ranging from shallow wells either at the sources of springs (La Fougeraie, site 11, Hudsons, site 12 and Hivernage, site 5) or with open shafts and water close to the surface (the Fregondee Valley wells, sites 4a and $4 \mathrm{~b}$ and La Conellerie, site 10) but more surprisingly also including several deeper wells such as Clos a Jaon (site 6), Le Fort (site 8) and La Tour (site 9), the latter of which was sealed with a wooden door. In Britain it is often recorded from many spring sites (L. Knight, personal records), which would explain its presence in many of the shallow wells with open shafts but the pathways by which it has colonised the deeper wells are unknown.

Large numbers of the cladoceran species Daphnia pulex Leydig, 1860 were recorded in two wells at Hougue Bie (sites 5 and 6) on Jersey. The first well (site 5), where it was recorded with $N$. aquilex and three species of Copepoda was $17 \mathrm{~m}$ deep with an open shaft at the surface, whilst the second (site 6 ) was much shallower $(3 \mathrm{~m})$ with a sealed shaft; no surface water-bodies were present nearby. On the surface $D$. pulex is widely distributed in mostly lentic habitats but is rarely recorded from subterranean waters; these records might represent a stygophilic population in the Hougue Bie area. 
The landhopper (terrestrial amphipod) Arcitalitrus dorrieni (Hunt, 1925) was recorded from a well in the garden of La Fougeraie on Sark (site 11), a shallow well at the source of a spring. Arcitalitrus dorrieni is an Australian species that was probably imported to Britain and Ireland by gardeners on exotic plants in the late $18^{\text {th }}$ and early $19^{\text {th }}$ centuries (O'Hanlon and Bolger 1997). It was first recorded in the Scilly Isles and from there spread to south west England (Barber and Gregory 2012). It occurs in damp humus, dead leaves or other decaying vegetation and has also been recorded from a shallow well on the Isles of Scilly (Knight 2008). In the British Isles it is known from Colonsay in the Inner Hebrides, several locations across Ireland, Cornwall, Dorset and the Royal Botanical Gardens at Kew (O'Hanlon and Bolger 1997). Recent (post 2001) surveys have also recorded it from the islands of Arran, Gigha and Bute, with further records from southern England, South Wales and along the west coast as far as Wester Ross in Scotland (Barber and Gregory 2012). It has also been reported from Guernsey (Howell 1989; Spicer and Tabel 1996) and Sark but is not known to be established elsewhere in northern Europe (Barber and Gregory 2012).

\section{Conclusion}

The investigation identified four species of stygobitic Crustacea in the groundwater of the Channel Islands. Niphargus aquilex was widespread across all four surveyed islands and did not appear to be restricted to any particular geology. Prior to the survey this species was known from a single site on Guernsey. Niphargus ladmiraulti was present in large numbers in a single borehole in the Bouley Bay Rhyolite on Jersey; it was not recorded from other sites in the same geological formation. This was the first record of this species from the archipelago and as it is a relatively common species in western France, it was surprising that it was not more widespread on the islands. Niphargus kochianus was collected from two sites in the Alderney Sandstone. Preliminary results from molecular studies have suggested that, although closer to France than the other islands, the lineages of both $N$. aquilex and $N$. kochianus on Alderney are more closely related to their respective populations in southern England rather than France, with the Alderney $N$. aquilex lineage being separate to the rest of the archipelago. The populations of $N$. aquilex on the other three islands form another distinct, highly divergent lineage, possibly representing a cryptic species. Historic records of $N$. kochianus and $N$. fontanus from Jersey were not confirmed, although it is likely that both species could also occur on the island.

The records of the syncarid Antrobathynella stammeri from two sites in the St. Ouen Sand on the west coast of Jersey are new for the island and possibly represent the first records of this species from the French bio-geographical area.

Several species of stygophilic Cyclopoida were also recorded during the survey, including the obligatory stygophilies Diacyclops bicuspidatus (Jersey, Guernsey and Sark) and D. languidus (Jersey) and the facultative stygophiles Diacyclops bisetosus, 
Eucyclops serrulatus and Paracyclops fimbriatus, recorded on all four islands, Macrocyclops albidus (Jersey) and Megacyclops viridis (Guernsey, Alderney \& Sark).

Various species of epigean freshwater invertebrates, including aquatic Diptera larvae the beetle Elmis aenea, Trichoptera larvae, molluscs and other Crustacea were mostly recorded from shallow wells close to surface streams.

The survey documented groundwater invertebrate communities that were surprisingly diverse for such relatively small islands. Future work on the archipelago, including sampling of the stream hyporheos, utilising methods such as the Bou-Rouch pump might result in the discovery of further species. The collection of $N$. kochianus and $N$. fontanus specimens from Jersey would be beneficial in confirming their presence on the island and providing material for future molecular studies to elucidate further the ancestry of the stygobitc lineages present on the archiplealgo. The similarities between populations of $N$. aquilex and $N$. kochianus on Alderney and those of southern England could indicate a possible "bridge" of cryptic speciation, migration and refuge during the last glaciations between mainland Europe and southern England.

\section{Acknowledgements}

Thanks to Colin Hayes and Hayley Gueno of the States of Jersey Department of the Environment for assistance during field work on the island. Thanks to Charles David of Guernsey Biological Records Centre and La Société Guernsiaise for assistance in selecting sampling sites on Guernsey. Thanks to Jo Birch of La Société Serquiaise for assistance in selecting sampling sites on Sark and for her kind offer of accommodation during the field work, also thanks to Lucy Belfield for assistance during the field work. Thanks to Roland Gauvain and staff at the Alderney Wildlife Trust for assistance during the field work and the identification of sampling sites on the island.

Thanks to Terry Gledhill of the Freshwater Biological Association for confirmation of the Antrobathynella specimens from Jersey and examination of the Acari for aquatic species.

The authors are grateful to Octavian Pacioglu and Marie-Jose Olivier for their useful comments and suggestions for improvement on an earlier draft of the paper.

Many thanks to and appreciations of the kindness of the many islanders who gave permission for sampling to take place in their private wells and boreholes.

\section{References}

Arnscheidt J, Hahn HJ, Fuchs A (2008) Aquatic subterranean Crustacea in Ireland: results and new records from a pilot study. Cave and Karst Science 35(1 \& 2): 53-58.

Arnscheidt J, Dooley J, Eriksson K, Hack C, Hahn HJ, Higgins T, Mc Carthy TK, McInerney C, Wood P (2012) Biogeography and Ecology of Irish Groundwater Fauna: assessment of 
the distribution, structure and functioning of subterranean fauna within Irish groundwater systems (2007-W-MS-1-S1) STRIVE Report. Environmental Protection Agency STRIVE Report series No. 95, EPA STRIVE Programme 2007-2013.

Barber T, Gregory S (2012) Non-native species ecology and distribution: the non-native terrestrial amphipod Arcitalitrus dorrieni. http://www.brc.ac.uk/downloads/Presentations/2012_TonyBarber_Amphipod.pdf

Belfield F (2012) Sark rocks. Small Island Publishing \& La Société Sercquaise, Sark, Channel Islands, $60 \mathrm{pp}$.

Bishop AC, Bisson G (1989) Classical areas of British geology: Jersey: description of $1: 25,000$ Channel Islands Sheet 2. Her Majesty's Stationery Office for British Geological Survey, London.

Botosaneanu L (1986) Stygofauna Mundi: a faunistic, distributional and ecological synthesis of the world fauna inhabiting subterranean waters (including the marine interstitial). E.J. Brill, Leiden, 740 pp.

British Geological Survey (2000) Guernsey, 1 : 250,000 solid geology. British Geological survey, Keyworth.

Camacho AI, Valdecasas AG (2008) Global diversity of syncarids (Syncarida; Crustacea) in freshwater. Hydrobiologia 595: 257-266. doi: 10.1007/s10750-007-9021-5

Chapman PRJ (1979) The biology of Otter Hole, near Chepstow. Transactions of the British Cave Research Association 6: 159-167.

Cheney CS, Davies J, Darling WG, Rukin N, Moon B (2006) Jersey Deep Groundwater Investigation. British Geological Survey BGS Commissioned Report, CR/06/221C, 151 pp.

Cvetkov L (1968) Un filet phréatobiologique. Bulletin de l'Institut de Zoologie et Musée, Sofia 22: $215-219$.

Davies AC (1998) Water budget analysis - Sark. With special reference to the possible future problem of saline intrusion. Technical Report, Oxford Brooks University.

Dole-Olivier MJ, Castellarini F, Coineau N, Galassi DMP, Martin P, Mori N, Valdecasasas A, Gibert J (2009) Towards an optimal sampling strategy to assess groundwater biodiversity: comparison across six European regions. Freshwater Biology 54(4): 777-796. doi: $10.1111 / j .1365-2427.2008 .02133 . x$

Einsle U (1993) Crustacea, Copepoda: Calanoida und Cyclopoida. Süßwasserfauna von Mitteleuropa, 8/4-1. Gustav Fischer Verlag, Stuttgart, 209 pp.

Fiers F (2007) Antrobathynella stammeri (Jakobi, 1954): the first record of Bathynellacea (Crustacea : Syncarida) in Belgium. Belgian Journal of Zoology 137(1): 115-116.

Ginet R (1996) Bilan systéematique du genre Niphargus en France. Laboratoire D’Hydrobiologie et Écologie Souterraines, Lyon, 242 pp.

Gledhill T, Sutcliffe DW, Williams WD (1993) British freshwater Crustacea Malacostraca: a key with ecological notes. Freshwater Biological Association, Scientific Publication No. 52., Ambleside, 173 pp.

Hänfling B, Douterelo-Soler I, Knight L, Proudlove G (2008) Molecular studies on the Niphargus kochianus group (Crustacea: Amphipoda: Niphargidae) in Great Britain and Ireland. Cave and Karst Science 35: 35-40. 
Harris PM, Roosa BR, Norment L (2002) Underground dispersal by Amphipods (Crangonyx pseudogracilis) between temporary ponds. Journal of Freshwater Ecology 17: 589-594. doi: $10.1080 / 02705060.2002 .9663936$

HCRS (2014) Database of the Hypogean Crustacea Recording Scheme. http://hcrs.freshwaterlife.org [accessed December 2014]

Howell AC (1989) Arcitalitrus dorrieni (Hunt) a recent addition to the Guernsey fauna. Report and Transactions of La Société Guernesiaise 22: 508.

Institute of Geological Sciences (1982) Jersey, Channel Islands Sheet 2, $1: 250,000$ solid and drift geology. Institute of Geological Sciences, Keyworth.

Jones RL, Keen DH, Birnie JF, Waton PV (1990) Past landscapes of Jersey. Environmental changes during the last ten thousand years. Pub. Société Jersiaise, Pier Road, Jersey, Channel Islands.

Karaman GS, Ruffo S (1986) Amphipoda: Niphargus group (Niphargidae sensu Bousfield, 1982). In: Botosaneanu L (Ed.) Stygofauna Mundi A faunistic, distributional and ecological synthesis of the world fauna inhabiting subterranean waters (including the marine interstitial). E. J Brill, Leiden, 514-534.

Keen DH (1978) The Pleistocene deposits of the Channel Islands. HMSO for Institute of Geological Sciences, London, Report 78/26.

Keen DH (1981) The Holocene deposits of the Channel Islands. HMSO for Institute of Geological Sciences, London, Report 81/10.

Knight LRFD (2008) A survey of the groundwater fauna of the Scilly Isles, United Kingdom. Cave and Karst Science 35(1 \& 2): 63-68.

Knight LRFD (2011) The aquatic macro-invertebrate fauna of Swildon's Hole, Mendip Hills, Somerset, UK. Cave and Karst Science 38(2): 81-92.

Knight LRFD (2014) Pen Park Hole Invertebrate Survey. http://www.penparkhole.org.uk/ resources/Pen_Park_Hole_Biological_Report_2013.pdf

Knight L, Penk M (2010) Groundwater Crustacea of Ireland, a survey of the stygobitic Malacostraca in caves and springs. Biology and Environment: Proceedings of the Royal Irish Academy 110B(3): 211-235.

Lees GJ (1990) The geochemical character of late Cadomian extensional magmatism in Jersey, Channel Islands. In: Geological Society Special Publication No. 51: The Cadomian Orogeny: 273-291. doi: 10.1144/GSL.SP.1990.051.01.17

Le Seur RF (1960) Marine zoological report for 1959. Annual Bulletin, Société Jersiaise 17: 303-304.

McInerney CE, Maurice L, Robertston AL, Knight LRFD, Arnscheidt J, Venditti C, Dooley JSG, Mathers T, Matthijs S, Erikkson K, Proudlove GS, Hänfling B (2014) The ancient Britons: groundwater fauna survived extreme climate changes over tens of millions of years across NW Europe. Molecular Ecology 23(5): 1153-1166. doi: 10.1111/mec.12664

Mezek T, Simčič T, Arts MT, Brancelj A (2010) Effect of fasting on hypogean (Niphargus stygius) and epigean (Gammarus fossarum) amphipods : a laboratory study. Aquatic Ecology 44(2): 397-408. doi: 10.1007/s10452-009-9299-7

Nichols RAH, Hill AE (2004) Jersey Geology Trail. Private publication printed by The Charlesworth Group. 
Notenboom J, De Boom K (1990) First record of the groundwater crustaceans Bathynellacea in the Netherlands. Beaufortia 41(22): 159-162.

O'Hanlon RP, Bolger T (1997) Biomass, growth and secondary production of Arcitalitrus dorrieni (Crustacea: Amphipoda: Talitridae) at two sites in Co. Galway, Ireland. Journal of the Zoological Society of London 241: 409-428. doi: 10.1111/j.1469-7998.1997.tb04834.x

Proudlove GS, Wood PJ, Harding PT, Horne DJ, Gledhill T, Knight LRFD (2003) A review of the status and distribution of the subterranean aquatic Crustacea of Britain and Ireland. Cave and Karst Science 30(2): 53-74.

Renouf J (2009) How has Jersey's climate changed in the last 50,000 years? In Turning Point. The ECO-ACTIVE guide to the science and impacts of climate change in Jersey. States of Jersey, Environment and Planning Department, Section 1.6.

Roach RA, Topley CG, Brown M, Bland AM, D’Lemos RS (1991) Outline and guide to the geology of Guernsey. Monograph No. 3. Guernsey Museum, Guernsey.

Robins NS, Smedley PL (1998) The Jersey groundwater study. British Geological Survey Research Report RR/98/5.

Robins NS, Griffiths KJ, Merrin PD, Darling WG (2000) Reconnaissance hydrogeological survey of Guernsey. Hydrogeology Series Technical Report WD/00/07. British Geological Survey, Keyworth.

Robins NS, Griffiths KJ, Merrin PD, Darling WG (2002) Sustainable groundwater resources in a hard-rock island aquifer - the Channel island of Guernsey. In: Hiscock KM, Rivett MO, Davison RM (Eds) Sustainable Groundwater Development. Geological Society, London. Special Publications 193: 121-132. doi: 10.1144/GSL.SP.2002.193.01.10

Robins NS, Rose EPF, Cheney CS (2012) Basement hydrogeology and fortification of the Channel Islands: legacies of British and German military engineering. Geological Society of London, Special Publications 362: 203-222. doi: 10.1144/SP362.11

Rose EPF (2005) The first hydrogeological maps of Jersey, Channel Islands: work by Walther Klupfel in 1942 and Richard Nelson c.1828. Proceedings of the Geologists' Association 116(2): 107-116.

Spicer JI, Tabel H (1996) Notes on the occurrence of the introduced landhopper Arcitalitrus dorrieni (Hunt, 1925) on Guernsey, Channel Islands. Journal of Natural History 30(11): 1626-1632. doi: 10.1080/00222939600770951

Stoch F (2010) How many species of Diacyclops? New taxonomic characters and species richness in a freshwater cyclopoid genus (Copepoda, Cyclopoida). Hydrobiologia 453/454: 525-531. doi: 10.1023/A:1013191429008

Stock JH, Gledhill T (1977) The Niphargus kochianus-group in North-Western Europe. Crustaceana Supplement 4: 212-243.

Tribe IR, D'Lemos RS, Strachan RA (1993) The foliated granitic rocks of western Alderney, Channel Islands: fabric origin and interpretation of 40Ar/39Ar mineral cooling ages. Proceedings of the Ussher Society 8: 186-188.

Trontelj P, Douady CJ, Fišer C, Gibert J, Gorički S, Lefébure T, Sket B, Zakšek V (2009) A molecular test for cryptic diversity in ground water: how large are the ranges of macrostygobionts? Freshwater Biology 54: 727-744. doi: 10.1111/j.1365-2427.2007.01877.x

Vandel A (1964) Biospeléologie: la biologie des animaux cavernicoles. Gauthier-Villars, Paris, 619 pp. 
Vibert Scrutiny Panel (2004) Draft water Resources (Jersey) law 200- transcript of evidence, provided to the Vibert Scrutiny Panel by George Langlois, Water Diviner and Lewis de la Haye, Well Driller. Public Hearing Session on 26th July 2004, Section 25.

Vonk R (1988) The Niphargus kochianus-group (Crustacea, Amphipoda) in the Aquitanian Basin, South-Western France, and a supposed case of introgressive hybridization. Stygologia 4: 177-191.

Walker AO, Hornell J (1896) Report on the Schizopoda, Cumacea, Isopoda and Amphipoda of the Channel Islands. The Journal of Marine Zoology \& Microscopy 2(7): 49-55.

Wood PJ, Gunn J, Perkins J (2002) The impact of pollution on aquatic invertebrates within a subterranean ecosystem - out of sight out of mind. Archive für Hydrobiologie 155: 223-237. 


\section{Supplementary material I}

Table 2: Invertebrate taxa recorded from wells and boreholes on Jersey

Authors: Lee R.F.D. Knight, Anton Brancelj, Bernd Hänfling, Colin Cheney

Data type: occurrence

Explanation note: List of taxa recorded on Jersey.

Copyright notice: This dataset is made available under the Open Database License (http://opendatacommons.org/licenses/odbl/1.0/). The Open Database License $(\mathrm{ODbL})$ is a license agreement intended to allow users to freely share, modify, and use this Dataset while maintaining this same freedom for others, provided that the original source and author(s) are credited.

\section{Supplementary material 2}

Table 3: Invertebrate taxa recorded from wells, boreholes and springs on Guernsey Authors: Lee R.F.D. Knight, Anton Brancelj, Bernd Hänfling, Colin Cheney

Data type: occurrence

Explanation note: List of taxa recorded on Guernsey.

Copyright notice: This dataset is made available under the Open Database License (http://opendatacommons.org/licenses/odbl/1.0/). The Open Database License $(\mathrm{ODbL})$ is a license agreement intended to allow users to freely share, modify, and use this Dataset while maintaining this same freedom for others, provided that the original source and author(s) are credited.

\section{Supplementary material 3}

Table 4: Invertebrate taxa recorded from wells and boreholes on Alderney Authors: Lee R.F.D. Knight, Anton Brancelj, Bernd Hänfling, Colin Cheney Data type: occurrence

Explanation note: List of taxa recorded on Alderney.

Copyright notice: This dataset is made available under the Open Database License (http://opendatacommons.org/licenses/odbl/1.0/). The Open Database License $(\mathrm{ODbL})$ is a license agreement intended to allow users to freely share, modify, and use this Dataset while maintaining this same freedom for others, provided that the original source and author(s) are credited. 


\section{Supplementary material 4}

Table 5: Invertebrate taxa recorded from wells and boreholes on Sark

Authors: Lee R.F.D. Knight, Anton Brancelj, Bernd Hänfling, Colin Cheney

Data type: occurrence

Explanation note: List of taxa recorded on Sark.

Copyright notice: This dataset is made available under the Open Database License (http://opendatacommons.org/licenses/odbl/1.0/). The Open Database License $(\mathrm{ODbL})$ is a license agreement intended to allow users to freely share, modify, and use this Dataset while maintaining this same freedom for others, provided that the original source and author(s) are credited. 